Research article / Научная статья

\title{
Cooperation between Russia and Germany in the field of energy policy in the XX-XXI centuries
}

\author{
E.A. Babintseva*, L.V. Ponomarenko \\ Peoples' Friendship University of Russia, \\ 10 k2, Miklukho-Maklay street, Moscow, Russian Federation, 117198 \\ *Corresponding author: babintseva-ea@rudn.ru
}

\begin{abstract}
The author devoted the paper to the peculiarities of bilateral cooperation between Russia and Germany in the field of maintaining a favourable environmental balance. The author notes that nature protection for a long time was not considered as a subject of interstate cooperation and did not fall into the focus of the agenda of important international summits. In connection with a number of historical reasons, at the beginning of the last century there was minimal state interest in organizing the protection of protected areas, conducting stabilization and supporting environmental measures, as well as ensuring the conservation and renewability of natural resources. The extensive path of economic development, the devastating military operations and the assessment of the natural environment as a resource basis for achieving primary state tasks contributed to the development of the global environmental crisis by the middle of the 20th century. The paper emphasizes that the starting point of international environmental cooperation and the adoption of a number of universal environmental acts were reports within the framework of the Club of Rome and further multilateral summits on climate and environmental issues dating back to the second half of the 20th century. The author assigns a special role within the framework of Russian-German environmental cooperation to the Nord Stream and Nord Stream-2 gas pipelines. The author emphasizes that cooperation within the framework of the projects took place in the context of the Western sanctions on Russia. Using energy projects as an example, the author showed in action the environmental relationship in the process of fuel and energy dialogue between partner countries. Based on an analysis of the results achieved, the author concludes that the future environmental cooperation between Russia and Germany is promising.
\end{abstract}

Keywords: Russia, Germany, environmental cooperation, Nord Stream, Nord Stream-2, "eco" orientation, ecocentrism, nature conservation, Baltic region, Kurgalsky reserve

Article history: Received: 10.12.2020. Accepted: 20.02.2021.

For citation: Babintseva E.A., Ponomarenko L.V. Environmental cooperation between Russia and Germany in the field of energy policy in the XX-XXI centuries // RUDN Journal of World History. 2021; 13(2):238-250. DOI: 10.22363/2312-8127-2021-13-2-238-250

(C) Babintseva E.A., Ponomarenko L.V., 2021

(c) (i) This work is licensed under a Creative Commons Attribution 4.0 International License https://creativecommons.org/licenses/by/4.0/ 


\title{
Сотрудничество России и Германии в сфере энергетической политики в XX-XXI вв.
}

\author{
Е.А. Бабинцева*, Л.В. Пономаренко \\ Российский университет дружбы народов, \\ 117198, Российская Федерация, г. Москва, ул. Миклухо-Маклая, д. 10, к. 2 \\ *babintseva-ea@rudn.ru
}

\begin{abstract}
Аннотация. Авторы посвятили статью особенностям двустороннего взаимодействия России и Германии в области поддержания благоприятного баланса окружающей среды. Авторами отмечается, что длительное время охрана природы не рассматривалась в качестве предмета межгосударственного сотрудничества и не попадала в фокус повестки дня важных международных встреч на высшем уровне. В связи с рядом исторических причин еще в начале прошлого века отмечается минимальный государственный интерес к вопросу организации охраны заповедных зон, проведению стабилизационных и поддерживающих природоохранных мероприятий, а также обеспечению сохранности и возобновляемости природных ресурсов. Экстенсивный путь экономического развития, разрушительные военные действия и оценка природной среды в качестве ресурсного базиса для достижения первостепенных государственных задач способствовали развитию глобального экологического кризиса уже к середине XX в. В статье подчеркивается, что отправной точкой международного экологического сотрудничества и принятия ряда всеобщих природоохранных актов стали доклады в рамках работы Римского клуба и последовавшие за ними многосторонние встречи на высшем уровне, посвященные климатическим и природоохранным проблемам и датированные уже второй половиной XX в. Особенную роль в рамках российского-германского природоохранного сотрудничества автор отводит газопроводным магистральным проектам «Северный поток» и «Северный поток - 2». Авторами подчеркивается, что сотрудничество в рамках проектов происходило в условиях санкционного воздействия Запада на Россию. На примере энергетических проектов авторы показали в действии экологическое взаимоотношение в процессе топливно-энергетического диалога между странами-партнерами. На базе анализа достигнутых результатов авторы приходят к выводу о перспективности дальнейшего экологического сотрудничества между Россией и Германией.
\end{abstract}

Ключевые слова: Россия, Германия, экологическое сотрудничество, Северный поток, Северный поток - 2, «эко» ориентация, экоцентризм, охрана природы, Балтийские регион, Кургальский заказник

История статьи: Поступила в редакцию: 10.12.2020. Принята к публикации: 20.02.2021.

Для цитирования: Babintseva E.A., Ponomarenko L.V. Environmental cooperation between Russia and Germany in the field of energy policy in the XX-XXI centuries // Вестник Российского университета дружбы народов. Серия: Всеобщая история. 2021. Т. 13. № 2. С. 238250. DOI: $10.22363 / 2312-8127-2021-13-2-238-250$

\section{Introduction}

Environmental history as an object of research in science, in particular, in Russia, began to be considered relatively recently. This is largely due to disputes arising in the context of the interpretation of this term. The question is related to 
whether to correlate it with the history of the development of environmental science as a field of natural science, or the term still refers to the environmental policy of states and interstate relations. First used in American historiography, the term "environmental history" in modern science can be interpreted as the interaction of Man and Nature in time [1. P. 10], which is far from the only definition. This formulation includes not only the completeness of the national approach to the study of this issue, but also touches upon moral, ethical, ideological and general humanitarian issues in the context of the relationship between the individual and the natural environment.

The topic of this article touches on the issue of international cooperation from the point of view of researchers of environmental history, which is undoubtedly important for filling the gaps and creating a connecting material for historical, political science, environmental and legal research related to international relations. In this regard, the attention of the authors was drawn to the experience of relations between Russia and Germany on topical energy issues. The choice of Germany as one of the subjects of relations is justified by the fact that this state has significant experience in the field of environmental protection. In just a few decades Germany has managed to overcome the crisis state of the environment and broken out into the pan-European leaders in terms of environmental protection. The research topic is of particular relevance in connection with the construction of the Nord Stream and Nord Stream-2 energy pipelines.

At present a fairly small number of scientific works have been devoted to direct consideration of the problem of relations between Russia and Germany in the environmental context. In the course of the study, the authors turned to both scientific research from various fields of knowledge in Russian, English and German, as well as publicistic sources and news reports from the media, materials on the official websites of important energy projects, presented for wide access.

In the course of the study, general scientific methods were used, the authors adhered to a systematic approach, which made it possible to consider the common problems of Russia and Germany in the field of energy cooperation and environmental protection. The method of historicism allowed to consider the continuity in the interaction of the parties. In the course of studying political interaction and events covered in the media, the method of analysis and synthesis was actively used.

Initially, the authors of the study set the goal of identifying the main factors of interaction between Russia and Germany, one way or another affecting the environment, in particular, in the energy field of cooperation. Also, the purpose of the study was to identify the main problems and prospects that arose in the course of cooperation between both subjects, which in the future can be used to continue the study of relations between Russia and Germany regarding the environment.

In its historical retrospect, it can be observed that domestic measures to protect, restore the environment and renewable natural resources were practiced several centuries ago. It is important to note that at the same time they were not associated with conscious environmental regulation in the modern understanding of this process. The main goal of both Russia and Germany for a long time remained the preservation of nature as the main raw material base for the implementation of 
state goals. This process is especially vividly observed in the development of forestry, and also reserve management and studies. Thus, a number of authors note measures according to which a special procedure for forest use in protected groves was established at the legislative level at the boundary of environmental legislation. Thus, due to restrictions and penalties imposed for cutting ship tree species in the 18th century, the renewability of the wood resource and the stable functioning of the Russian fleet were ensured [2. P. 29-35; 3. P. 171]. In Germany, the practice of compensatory forestry was known in the XIV-XV centuries yet [4. P. 7-11].

The period of the late XIX - early XX centuries is characteristic of large European powers as a period reflecting the consequences of the industrial revolution of past years, as well as a period of formation of an industrial economy. The development of industry, especially the heavy one, could not but affect all the basic indicators and factors of the vital activity of society. If in 1800 the world population was 906 million people, then in 1850 it was 1171 million, and 1608 million in 1900. In the XIX century, the average annual population growth rate of the two largest industrial countries in Europe, the UK and Germany, amounted to over 1\%. At this rate, doubling is achieved in 70 years. In Russia over the same period, the average annual rate was $2 \%$ [5. P. 1]. Within the indicated range of years, active population growth and general economic growth were observed, which implies increased anthropogenic interference and environmental destabilization.

International cooperation in the field of environmental protection directly received its development only in the second half of the 20th century. This was largely due to the development of a conscious and focused nature of environmental regulation. As noted in reports of the Club of Rome, UN environmental conferences (Stockholm 1972), as well as the adoption of a number of international legal acts, the very paradigm of human attitude to nature has changed for the first time in the history of mankind.

At that time, the main goal of human influence on nature was not compensation for extensive consumption and not ensuring the preservation of economic benefits. The basis for environmental protection was the provisions related to the conscious responsibility of man to nature: saving biodiversity, minimizing damage from major environmental disasters, preserving the ecosystem for future generations. A number of terms have appeared in industrial environmental areas of science reflecting a new approach to the relationship between man and nature. So, in the sections of modern ecophilosophy and ecopsychology, the concept of "Ego" and "Eco" orientations was introduced: the phenomena characteristic of extensive anthropocentrism and intensive ecocentrism, respectively [6. P. 34].

The phenomenon of "eco" orientation should not be regarded as a modern trend or marketing move that exists in the interests of commercial organizations and the support of market mechanisms. In Germany, environmental friendliness becomes a conscious priority in comparison with a comfortable personal choice of consumer demand and lifestyle as a result of the mass ecologization of upbringing and the specifics of the environmental educational process. Environmental attractiveness is the basis of associative identification with the quality of goods and services that do not harm the already exhausted environment. In Russia, the 
collective terms "Deutsche Qualität" and "Made in Germany" have become a household name, synonymous with the concept of high quality.

Today, both states have a wide range of cooperation in the field of cultural relations, scientific, economic and environmental potential of countries.

Every year, cooperation between Russia and Germany finds expression in the framework of joint meetings, scientific conferences and congresses, where an exchange of environmental experience, as well as consultative events is carried out. A similar type of consultation dedicated to the integration of advanced technologies and economic development was deliberately held by Germany for the Russian side in 2012. As a result of the events, a Declaration was adopted to accompany the solution of problems raised during the meetings.

According to the Declaration, the German Society for International Cooperation (GIZ), which appears in the majority of environmental events in Russia and Germany, was instructed to provide technical support to the Ministry of Natural Resources of Russia [7]. At the same time, there is a high level of interest of the German side in the cooperation with Russia on climate change issues [8. P. 108].

For many years, the priority area in relations between Russia and Germany was the economy, in particular, the fuel and energy policy of states. Obviously, Russia has a significant advantage as the largest supplier of energy resources to Europe, which provides the Russian state with a number of economic and political benefits. Of course, bilateral relations presuppose, as German Chancellor A. Merkel noted, "interpenetration" of the interests of states. At the same time, the negative reaction of competing states to the appearance of rivals providing more favourable terms of supply is inevitable [9. P. 159].

On March 17, 2014, Merkel accused Russia of escalating the conflict in Ukraine and announced the possible introduction of anti-Russian sanctions by the European Union, including "measures against specific individuals responsible for exacerbating the situation." [Weißbuch zur Sicherheitspolitik und zur Zukunft der Bundeswehr 2016] Nevertheless, Germany was oriented to restore relations between Russia and the West due to its dependence on energy supplies from the Russian Federation and its interest in the operation of Nord Stream and Nord Stream-2 [10. P. 148-149]. The least favourable moment in this situation is that states often use indirect methods in competitive political and economic struggle for spheres of influence. So, pressure on the economy and state policy can be carried out by speculative methods and abuses in the field of environmental protection, just as, on the contrary, there is a deliberate disregard for environmental standards for the sake of economic and political interests. According to some authors, a similar situation has developed in a number of environmental non-governmental organizations, whose opinion contained signs of political commitment against the construction of the gas pipeline "Nord Stream - 2" [11. P. 138-139].

\section{Environmental protection in the fuel and energy segment of cooperation}

Russia and Germany were in conditions of close mutually beneficial cooperation beginning from the times when gas pipes have been supplied from 
Germany in 1970 according to the project "Gaz - Truby", and up to modern cooperation on the construction of the Nord Stream and Nord Stream-2 gas pipelines. This is largely due to the geopolitical position of states. This was expressed in the combined use of Russian natural resources and the German scientific and technological base. It is extremely important in the context of this issue to touch on the fact that during any joint fuel and energy project with the participation of Russia and Germany, both states will invariably turn to general environmental standardization and international legal acts in the field of environmental protection. So, regarding the Nord Stream project and its expansion, Nord Stream-2, we are talking about Articles 122 and 124 of the UN Convention on the Law of the Sea, on the basis of which the Baltic Sea can be classified as "closed and semi-closed seas" [12].

Self-cleaning of this type of closed water reservoirs has extremely low rates; for this reason a number of difficulties have arisen related to the need to minimize the threats of environmental disasters, which is impossible not to take into account when working with energy resources. In the course of the construction, questions arose regarding the reduction of the construction corridor itself and the preservation of the hydrological characteristics of the terrain. In particular, Russia, Germany, Finland, Estonia, Denmark, Sweden, Latvia, Lithuania and Poland are washed by the Baltic Sea depending on the state of the marine environment and the shelf. The Baltic Sea also indirectly serves Belarus, the Czech Republic, Norway, Slovakia and Ukraine as a drainage basin. Despite the economic interest, the parties faced not only the need for pan-European coordination. So, back in 2018, a number of Russian and foreign media announced protests of the largest environmental associations regarding the construction of an additional Nord Stream-2 pipeline. It was reported that the World Wildlife Fund (WWF) and the German Conservation Union (NABU) sent letters to the German Chancellor A. Merkel and the chairman of the Christian Social Union (CSU) Holst Seehofer, as well as the leader of the Social Democratic Party (SPD) Martin Schulz [13]. According to the appeal of environmental experts, Nord Stream-2 was described as a "climatic and political deadlock threatening the vulnerable ecological system of the Baltic Sea and driving a wedge between solidarity and trust within the European Union" [14].

In this regard, one can observe a sharp politicization of the raised environmental issue. Nevertheless, it was emphasized that even despite the threat of lawsuits, the decision to build in the waters of the Baltic Sea was in full responsibility taken in advance on the part of Germany by the authorized Stralsund Municipal Department and the Federal Office for Maritime Navigation and Hydrography [13]. Despite the fact that the German branch of WWF made claims regarding the threat of the gas pipeline to preserve the protected area and the environmental safety of the Baltic region, it should be emphasized that this organization remains a charitable foundation, i.e. an international public organization, and does not express the views of the state leadership.

It was recognized by all parties that the Nord Stream-2 commercial project should not be used for political purposes [15. P. 76]. The answer was also voiced on the Russian side by the General Director for Gas Projects of the National Energy 
Security Fund A.I. Grivach. It was announced that Nord Stream-2 poses no threat to the Baltic ecology. This was proved by the previous Nord Stream project, which passed a high level of environmental regulation and audits [16]. Moreover, as a result of the analysis devoted to the harmfulness of its environmental impact, it was found that the largest percentage of greenhouse gas emissions occur during the delivery of natural gas to the EU via the Ukrainian corridor, and the smallest through the Nord Stream [17. P. 8]. This fact underlines the greatest environmental feasibility of the project. "Environmental phobias" were actively used to torpedo the first "Nord Stream" by critics in Central and Eastern Europe, in particular Poland and Lithuania. The trouble-free operation of the gas pipeline since its launch in 2011 has additionally shown the inconsistency of such arguments [18. P. 7]. Similar argumentation also goes along with the work according to the plan of the Nord Stream-2 project.

\section{Preservation of protected areas and the ecological balance of the Baltic region}

Due to the fact that, as a particularly weighty argument against the construction, it was stated that, in addition to the Baltic Sea basin, the pipeline runs on the territory of the Kurgalsky reserve in the Kingisepp district of the Leningrad region, a number of informational refutations of the environmental hazard of the project were published on the official website of the project both on the part of Russia, and on the part of Germany, as well as other European states. In addition to the obligations of the parties, the publications on the issuance of a building permit and the results of a study of local biomes with an environmental impact assessment (EIA), a special brochure was published; it was devoted directly to the impact of the Nord Stream-2 project on the reserve. A unique engineering approach of the parties to minimize damage to the soil and groundwater was noted in the brochure. In ecologically sensitive areas, for example, in wooded areas, the width of the corridor for laying the trench and its immediate depth were significantly reduced. Welding of pipes is carried out outside the territory of the reserve: finished chains are placed in a trench by pulling them. The use of heavy construction equipment was significantly reduced and technical means operate using biodegradable fuel. Noise level and interference with the natural biotic balance are limited; work is being carried out taking into account soil types and minimizing the impact on flora and fauna. On the part of Russia, the work has been noted towards achievement of multilevel control over compliance with environmental obligations. A special environmental monitoring program was timed to coincide with the project, involving a number of specialist contractors who compared the scale of actual work with an acceptable level of EIA. As an example, the organizers of the previous Nord Stream project invested an additional 40 million euros in a comprehensive environmental monitoring program. It included approximately 1000 stationary sampling points for measurements on 16 different environmental components during the construction phase and during the first three years of operation. The implementation of the project also included the work in the corridor of laying the gas pipeline on disposal of explosive ordnance that has remained in the Baltic Sea 
since the time of the World Wars [19. P. 125]. According to an independent assessment, the total investment will ultimately reach 9.5 billion euros, given the interest of all countries participating in the Nord Stream-2 project [20].

About 40 independent specialized contractors were involved in environmental monitoring. By the end of 2020, the volume of Nord Stream-2 investments in environmental surveys, analysis, monitoring and environmental activities will exceed 100 million euros [21]. About 30 monitoring stations on the offshore section and more than 20 integrated observation points on the coastal area carry out detailed monitoring under the supervision of Rosprirodnadzor, the Committee for State Environmental Supervision, Forest Management of the Leningrad Region, etc. External auditors were involved to oversee the entire pipe installation both from the outside Russia and Germany represented by the AllRussian Research Institute of Ecology, the Dutch international company Royal Haskoning DHV and the Environmental resource management (ERM) being a leading international organization in the field of environmental consultations [22].

In addition to the WWF protest, which activity focuses on a wide range of environmental issues, there are more narrowly focused organizations, such as the United Nations Environment Program and the International maritime organization, created within the UN to promote international scientific ideas on environmental protection and standardization of shipping, respectively. Also, there are more specific ones, such as The Information Office for the Baltic Proper in Stockholm, which are the result of the Swedish environmental bill and regulate the biochemical safety of the Baltic waters; German research institute GEOMAR - Helmholtz Center for Ocean Research Kiel, dealing with climate dynamics, marine ecology and biogeochemistry of water bodies; the Baltic Environmental Information Dissemination System project created in Germany, which promotes the ideas of transport and energy regulation in the Baltic region, as well as includes materials for the formation of a sustainable development concept; Coalition Clean Baltic, a large non-governmental organization in Helsinki created from an association of more than 25 non-profit organizations in the Baltic countries, including Russia, Germany, Finland, Latvia and others, involved in the protection of the Baltic Sea waters, and many others [23. P. 137-143].

As part of the presentation by Dirk von Ameln, Senior Advisor to the Executive Director of the Nord Stream-2 Project, the positive impact of the experience of building the previous energy supply mains was noted. He especially noted that Nord Stream-2 will surpass the first project in terms of safety and environmental protection [24].

It should be noted that the case of main pipeline energy projects is only a relevant example of the economic cooperation of adjacent states; it is interesting in that the situation entailed a tremendous environmental resonance, which required an immediate reaction from all the actors in the transaction.

The specifics of the interaction between Russia and Germany regarding environmental aspects is that, in addition to the nationwide interest, Germany has a point-wise regional interest of a number of domestic entities. In addition to hightech clusters and partner universities, the interaction extends to tenders, business projects and utilities. So, in 2014, a plant for the production of sodium hypochlorite 
was built in the south-east of Moscow replacing liquid chlorine in the process of water treatment in the capital's water supply. The construction tender was won by the German company WTE Wassertechnik $\mathrm{GmbH}$, which introduced its technologies into the daily water treatment process for Muscovites [25]. Collaboration with this contractor has occurred before. As part of a public-private partnership at the regional level, in 2009 the mini-TPP burning biogas produced at the Kuryanovsky treatment facilities was commissioned [26. P. 10].

\section{Conclusion}

Thus, the environmental cooperation between Russia and Germany is a series of processes that arise not only at the scientific level of interaction, but also in the course of solving global general political problems. In particular, the formulation of environmental objectives is becoming urgent in economic sectors during industrial and also fuel and energy cooperation, where it is highly likely that severe types of anthropogenic harm to the environment will be caused. Borrowing the best practices of partner countries is not only a path to progress and a good chance to implement bilateral partnerships and strengthen ties between states. Any kind of borrowing includes risks of a certain level of dependence on the state that provided the support. So, for example, this can be expressed in the lack of supply of parts for the operation of imported equipment when it is impossible to produce their affordable analogues in the borrowing country. Environmental cooperation at the beginning of the XX century deliberately progressed only thanks to the efforts of the scientific community. Only in the second half of the last century, when the issues of nature conservation and the environmental crisis began to be more often considered according to a separate agenda at international meetings, the interstate relations being built on the principle of fulfilling the norms of international environmental law became an engine in the development of the environmental paradigm. This kind of interaction leads to bilateral teamwork of partner entities representing different states. To one degree or another, the need to formulate and solve private environmental problems often arises during such interaction in business, scientific, fuel and energy, construction and other types of projects. A similar case was considered by the example of the route through the water and protected areas. Cases of environmental crimes and violations of generally recognized environmental protection standards, as well as general political issues that could influence positive decisions in the implementation of such projects were deliberately not considered in this context. Favourable experience in the field of environmental protection and ecological cooperation between Russia and Germany proves that further cooperation in these areas is a focused and desirable continuation of fruitful mutually beneficial cooperation between the states considered.

\section{REFERENCES}

[1] Durnovtsev VI. "Environmental History" as "Ecologicheskaya Istoriya" (Historiographical Notes). Bulletin of the Surgut State Pedagogical University. 2017 (6):10-19.

[2] Chernykh VV. Forest legislation during the reign of Peter I. Siberian Journal of Law. 2012. No 1 (56):29-35. 
[3] Istomina EG. Forestry of the provinces of European Russia in the 19th - early 20th centuries: management and protection mechanisms. Bulletin of the RSUH: Scientific journal: Academic Journal . 2014. No 17 (139):171.

[4] Straubinger J. Sehnsucht Natur: Geburt einer Landschaft. Salzburg: Umschlaggestaltung, Herstellung und Vertrag: Books on Demand GmbH, D-Notderstedt, 2009.

[5] Pogrebinskaya VA. To help those studying economic science. The Second Industrial Revolution. Economic Journal. 2005(10):1-133.

[6] Kolominsky YaL., Belanovskaya OV. Environmental consciousness of the individual: "ego" and "eco" orientation. Medical and social ecology of the individual: state and prospects: Proceedings of the IX International Conference, April 2-3, 2011, Minsk. Editorial board: VA. Prokasheva (editor-in-chief) [et. Al.] Minsk: Publishing Center of BSU, 2011. P. 34

[7] Bilateral cooperation with Russia in the field of environmental protection. Federal Ministry of Foreign Affairs of Germany. URL: https://germania.diplo.de/ ru-ru/themen/wirtschaft/umweltschutz-bilaterale-zusammenarbeit/1295438 [Accessed date: 01.05.2020]

[8] Basov FA. Energy and environmental cooperation between Russia and Germany. World Economy and International Relations. 2011. (8):108.

[9] Gamzalov SD. Russian-German relations: specifics and development prospects. Power. 2010(6).

[10] Avdeenko EG. Problems and prospects for the development of Russian-German relations (2000-2018). Magistra Vitae: electronic journal on historical sciences and archeology. 2018(2):146-153.

[11] Roginko SA. Nord Stream-2: Imaginary Environmental Risks. Scientific and Analytical Bulletin of the Institute of Europe, Russian Academy of Sciences. 2018(4):136-141.

[12] United Nations Convention on the Law of the Sea, Part IX, Art. 122-123. Website of the United Nations. URL: http://www.un.org/ru/documents/decl_conv/conventions/ pdf/lawsea.pdf [Accessed date: 10.04.2020].

[13] WWF und Nabu fordern Stopp von Nord Stream 2. Der Tagesspiegel. URL: https://www.tagesspiegel.de/politik/kritik-an-geplanter-erdgas-pipeline-wwf-undnabu-fordern-stopp-von-nord-stream-2/20835982.html [Accessed date: 23.04.2020].

[14] "Nord Stream - 2" does not threaten the ecology of the Baltic, expert says. RIA NEWS. URL: https://ria.ru/20180112/1512488457.html [Accessed date: 12.05.2020].

[15] Belov VB. The Nord Stream-2 Project - Opportunities and Risks of Implementation. Scientific and Analytical Bulletin of the Institute of Europe, Russian Academy of Sciences. 2018 (3):74-80.

[16] Expert believes Nord Stream 2 does not threaten the Baltic ecology. RIA NEWS. URL: https://ria.ru/20180112/1512488457.html [Accessed date: 05.12.2020]

[17] Aksyutin OE., Ishkov AG., Romanov KV., Pystina NB., Akopova GS., Kosolapova EV. Ecological efficiency of production and use of natural gas based on the assessment of the full life cycle. News of gas science. 2017, 33(5):3-11.

[18] Starikov SA. "Nord Stream-2": The dilemma of European energy interests. Internet Journal of Science of Science. Volume 9, No 6 (2017) [Digital source]: https://naukovedenie.ru/ PDF/132EVN617.pdf (free access) [Accessed date: 06.10.2020].

[19] Smirnov SV. Russia-Germany: Nordstream - an example of goodwill and effective cooperation (a difficult history of a large project) . Modern Europe. 2013, 54(2):116-128.

[20] Berkhahn A., Kruse M. Economic impact on Europe of the Nord Stream-2 project: Analysis of effects on job creation and GDP (2017). Arthur D Little, [Digital source]: https://www.adlittle.com/sites/default/files/viewpoints/adl_nord_stream_2_economic _impact-report.pdf [Accessed date: 01.07.2020]. 
[21] The results of the annual environmental monitoring confirm the conclusions of the environmental impact assessment report. Nord Stream 2. URL: https://www.nordstream2.com/en/dlia-pressy/novosti-i-meropriiatiia/rezultaty-ezhegodnogoekologicheskogo-monitoringa-podtverzhdaiut-zakliucheniia-otchiota-ob-otsenkevozdeistviia-na-okruzhaiushchuiu-sredu-141 [Accessed date: 06.19.2020].

[22] Nord Stream 2 in Russia: responsible implementation of the project in the Kurgalsky Reserve, November 2019. Official website of the Nord Stream project 2 (PDF). URL: https://www.nord-stream2.com/ru/download/document/388/ [Accessed date: 10.05.2020].

[23] Babintseva E., Mansur D., Trifonova E., Knyazeva V. — Cooperation On the issue of in-ternational cooperation in the field of protection of inland water objects using the example of the Baltic Sea References: 5th International Multidisciplinary Scientific Conference on Social Sciences and Arts SGEM 2018, www.sgemsocial.org, SGEM2018 Conference Proceedings, 26 August - 1 September, 2018, Vol. 5, Issue 1.2, P. 137-143.

[24] Von Ameln D. Choosing the route of the Nord Stream-2 project in Russia and the approach to biodiversity conservation. Nord Stream. St. Petersburg May 18, 2017 [Digital source] https://ccb.se/Evidence2017/NS2/Introduction_Route\%20selection\% 20round\%20table.pdf [Accessed date: 07.01.2020].

[25] Moscow Mayor opened a plant for the production of sodium hypochlorite. MVK Mosvodokanal. [Digital source] URL: http://www.mosvodokanal.ru/press/news/7064 [Accessed date: 07.11.2020].

[26] Faustova IL. Analysis of the implementation of regional energy saving infrastructure projects using public-private partnership mechanisms in the regions of Russia. Economic analysis: theory and practice. 2012, 31 (286):7-12.

\section{БИБЛИОГРАФИЧЕСКИЙ СПИСОК}

[1] Дурновцев В.И. «Environmental history» как «экологическая история» (Историографические заметки) // Вестник Сургутского государственного педагогического университета. 2017. No. 6. С. 10-19.

[2] Черных B.B. Лесное законодательство в период правления Петра I // Сибирский юридический вестник. 2012. № 1 (56). С. 29-35.

[3] Истомина Э.Г. Лесное хозяйство губерний европейской России в XIX - начале XX в.: механизмы управления и охраны // Вестник РГГУ: Научный журнал: Асаdemic JournalN. 2014. № 17 (139). C. 171.

[4] Straubinger J. Sehnsucht Natur: Geburt einer Landschaft. Salzburg: Umschlaggestaltung, Herstellung und Vertrag: Books on Demand GmbH, D-Notderstedt, 2009. 308 s.

[5] Погребинская B.A. В помощь изучающему экономическую науку. Вторая промышленная революция // Экономический журнал. 2005. № 10. С. 1-133.

[6] Коломинский Я.Л., Белановская О.В. Экологическое сознание личности: «эго» и «эко» ориентация // Медико-социальная экология личности: состояние и перспективы: Материалы IX Междунар. конф., 2-3 апр. 2011 г., Минск. / редкол.: В.А. Прокашева (отв. ред.) [и др.] - Мн.: Изд. центр БГУ, 2011. с. 34.

[7] Двустороннее сотрудничество с Россией в области защиты окружающей среды // Федеральное министерство иностранных дел Германии. URL: https:/germania.diplo.de/ ru-ru/themen/wirtschaft/umweltschutz-bilaterale-zusammenarbeit/1295438 (дата обращения: 01.05.2020).

[8] Басов Ф.А. Энергетическое и экологическое сотрудничество России и Германии // Мировая экономика и международные отношения. 2011. № 8. С. 108.

[9] Гамзалов С.Д. Российско-германские отношения: специфика и перспективы развития // Власть. 2010. № 6. с. 159. 
[10] Авдеенко Е.Г. Проблемы и перспективы развития российско-германских отношений (2000-2018) // Magistra Vitae: электронный журнал по историческим наукам и археологии. 2018. № 2. С. 146-153.

[11] Рогинко C.A. «Северный поток - 2»: мнимые экологические риски // Научно-аналитический Вестник Института Европы РАН. 2018. № 4. С. 136-141.

[12] Конвенция организации объединенных наций по морскому праву, ч. IX, ст. 122123 // Сайт Организации объединенных наций. URL: http://www.un.org/ru/documents/ decl_conv/conventions/pdf/lawsea.pdf (дата обращения: 10.04.2020).

[13] WWF und Nabu fordern Stopp von Nord Stream 2 // Der Tagesspiegel. URL: https://www.tagesspiegel.de/politik/kritik-an-geplanter-erdgas-pipeline-wwf-und-nabufordern-stopp-von-nord-stream-2/20835982.html (дата обращения: 23.04.2020).

[14] «Северный поток - 2» не угрожает экологии Балтики, считает эксперт // РИА НОBОСТИ. URL: https://ria.ru/20180112/1512488457.html (дата обращения: 12.05.2020).

[15] Белов В.Б. Проект «Северный поток-2» - шансы и риски реализации // Научноаналитический Вестник Института Европы РАН. 2018. № 3. С. 74-80.

[16] «Северный поток - 2» не угрожает экологии Балтики, считает эксперт // РИА НОBОСТИ. URL: https://ria.ru/20180112/1512488457.html (дата обращения: 12.05.2020).

[17] Аксютин О.Е., Ииков А.Г., Романов К.В., Пыстина Н.Б., Акопова Г.С., Косола$n о в а$ E.B. Экологическая эффективность производства и использования природного газа на основе оценки полного жизненного цикла // Вести газовой науки. 2017. № 5(33). C. 3-11.

[18] Стариковс A. «Северный поток-2»: Дилеммность европейских энергетических интересов // Интернетжурнал «Науковедение» Том 9, № 6 (2017) [Электронный pecypc]: https://naukovedenie.ru/PDF/132EVN617.pdf (доступ свободный) (дата обращения: 10.06.2020).

[19] Смирнов C.B. Россия-Германия: Nordstream - пример доброй воли и эффективного сотрудничества (непростая история большого проекта) // Современная Европа. 2013. № 2 (54). С. 116-128.

[20] Berkhahn A., Kruse M. Economic impact on Europe of the Nord Stream 2 project: Analysis of effects on job creation and GDP (2017) // Arthur D Little, [Электронный pecypc]: https://www.adlittle.com/sites/default/files/viewpoints/adl_nord_stream_2_ economic_impact-report.pdf (дата обращения: 01.07.2020).

[21] Результаты ежегодного экологического мониторинга подтверждают заключения отчёта об оценке воздействия на окружающую среду // Nord Stream 2. URL: https://www.nord-stream2.com/ru/dlia-pressy/novosti-i-meropriiatiia/rezultaty-ezhegodnogo-ekologicheskogo-monitoringa-podtverzhdaiut-zakliucheniia-otchiota-ob-otsenkevozdeistviia-na-okruzhaiushchuiu-sredu-141/ (дата обращения: 19.06.2020).

[22] «Северный поток - 2» в России: ответственная реализация проекта в Кургальском заказнике, ноябрь 2019 // Официальный сайт проекта Nord Stream 2 (PDF). URL: https://www.nord-stream2.com/ru/download/document/388/ (дата обращения: 10.05.2020).

[23] Babintseva E., Mansur D., Trifonova E., Knyazeva V. - Cooperation On the issue of in-ternational cooperation in the field of protection of inland water objects using the example of the Baltic Sea References: 5th International Multidisciplinary Scientific Conference on Social Sciences and Arts SGEM 2018, www.sgemsocial.org, SGEM2018 Conference Proceedings, ISBN 978-619-7408-62-1 / ISSN 2367-5659, 26 August - 1 September, 2018, Vol. 5, Issue 1.2, P. 137-143.

[24] Фон Амельн Д. Выбор маршрута проекта «Северный поток-2» в России и подход к сохранению биоразнообразия // Nord Stream. Санкт-Петербург 18 Мая 2017 [Электронный ресурс] https://ccb.se/Evidence2017/NS2/Introduction_Route\%20selection\%20round\%20table.pdf (дата обращения: 01.07.2020). 
[25] Мэр Москвы открыл завод по производству гипохлорита натрия // МВК Мосводоканал. [Электронный ресурc]. URL: http://www.mosvodokanal.ru/press/news/7064 (дата обращения: 07.11.2020).

[26] Фаустова И.Л. Анализ реализации инфраструктурных региональных проектов по энергосбережению с использованием механизмов государственно-частного партнерства в регионах России // Экономический анализ: теория и практика. 2012. № 31(286). C. 7-12.

\section{Information about the authors:}

Babintseva Ekaterina Alekseevna - Senior Lecturer, Candidate of Historical Sciences, Department of Foreign Languages, Faculty of Humanities and Social Sciences, Peoples' Friendship University of Russia, e-mail: babintseva-ea@rudn.ru

Ponomarenko Lyudmila Vasilievna - Doctor of Historical Sciences, Professor, Department of International Relations, Faculty of Humanities and Social Sciences, Peoples' Friendship University of Russia, e-mail: ponomarenko-lv@ rudn.ru

\section{Информация об авторах:}

Бабинщева Екатерина Алексеевна - кандидат исторических наук, старший преподаватель кафедры иностранных языков факультета гуманитарных и социальных наук Российского университета дружбы народов, e-mail: babintseva-ea@rudn.ru

Пономаренко Людмила Васильевна - доктор исторических наук, профессор кафедры международных отношений факультета гуманитарных и социальных наук Российского университета дружбы народов, e-mail: ponomarenko-lv@rudn.ru 